\title{
Small Islands versus Big Cities: Lessons in the Political Economy of Regional Development from the World's Small
}

Islands

Godfrey Baldacchino

\begin{abstract}
Population, employment and economic capacity continue to concentrate in and around large urban centres. If geography (measured as proximity to large centres of population) increasingly matters in the knowledge economy, then there may be no future for periphery locations. This paper critically reviews and refutes this hypothesis by looking at the world's small islands. Handicapped by size and distance, they are unable to generate scale dynamics nor to regularly access any neighbouring, large metropolitan centres. Nevertheless, jurisdictional resourcefulness resulting from sovereignty or subnational autonomy fosters compensatory policy capacity. Demand for niche-technology manufactures and craft-based, labour-intensive or place-specific services is likely to persist. Cyclical migration strategies allow islanders seeking work or education off island to tap the metropole and re-inject resources to reinvigorate the periphery. Remittances, aid, bureaucracy and other "rents" can provide significant fiscal resources necessary for survival.
\end{abstract}

Key words: innovation, space, knowledge, regions.

JEL Classification: O11, P16

\section{Introduction}

The relationship between cities and urban economies is becoming increasingly more important than the relationship between countries. Population, employment and economic capacity continue to concentrate in and around large urban centres. Globalisation and global competitive trends are leading to the greater concentration of resources associated with the modern economy (high-tech industries, flexible IT-skilled labour pools, re-

Canada Research Chair in Island Studies

University of Prince Edward Island

550, University Avenue, Charlottetown

Prince Edward Island

Canada C1A 4 P3

E-mail: gbaldacchino@upei.ca search and development institutes, ICT-specializing universities) in large urban centres and metropolitan areas. This trend suggests that new technologies are not altering a pattern of concentration ushered in by industrialisation; but are actually helping to fuel it. It appears that geography (measured as proximity to large centres of population) increasingly matters in the knowledge economy; while contemporary success (measured in terms of economic viability) is synonymous with being a successful knowledge economy. "The world, economically and in management terms, has become a network of ... prosperous cityregions" (Ohmae, 2001, p. 33).

The implications of such an assessment spell the demise of periphery locations. Any location that is unable to muster a significant knowledge critical mass will find itself exporting people, brains, investment and other forms of capital to attractive metropolitan zones or their immediate suburbs. Employment opportunities will fall; actual entrepreneurs will move away; potential ones will look askance. The young and educated people will relocate first, often never to return but to visit relatives and friends. A decreasing population reduces the political clout of the peripheral community, making the resort to political solutions to the adverse condition less likely; while the availability of stateof-the-art, public infrastructure (as in roads, health care, education) also declines.

This dynamic appears irreversible. It is borne out by demographic statistics, concentration of knowledge industries and investment flows. Are therefore all peripheries meant to suffer, sooner or later, a haemorrhage of human and other, economic resources? Is such a demographic shift laudable both from an 'economies of scale' 
perspective, as well as with regard to the improved quality of life of the beneficiaries?

This paper seeks insights towards answering this fundamental question by looking at extreme, peripheral locations. In so doing, it adopts a methodological approach recommended by Wright Mills (1959, p. 207), whereby the investigation of extreme and opposite case scenarios can facilitate a bettering understanding of specific trends. These locations are small islands: structurally cheated of economies of scale and institutional "thickness" (after Amin and Thrift, 1994, pp. 14-15) as well as burdened with the double handicap of insularity and distance from more heavily populated mainlands, where metropolitan centres are invariably located. They are amongst the most poorly equipped to respond to the challenges of the technological age. How are small islands faring in a world that favours big cities? How can they hope to muster the resources to become knowledge economies? How well do small islands - often, by definition, peripheral regions - provide interesting lessons in the political economy of regional development?

Answers to these questions should reveal the extent to which: "success" today is co-terminous with knowledge capitalisation; how far does distance impede development; and how uni-dimensional the definition of "development" is meant to be.

\section{An integrating global economy; a splintering global polity}

The recent dominant trend in world economics has been the dismantling of trade barriers and the increasingly seamless freedom of movement of people, money, goods and services across borders. In such a context, capital and skills associated with the knowledge economy have been concentrating with a spectacular speed. The sprawl of metropolitan areas embracing leading-edge players spells an increasing rate of decline for peripheral regions, with their members on one hand increasingly thwarted of the opportunities associated with the knowledge economy; while, on the other hand, increasingly able, willing or obliged to migrate. People, like capital, tend to be drawn from periphery to core.
Meanwhile, and in apparent contrast, a dominant trend in world politics over recent decades has been for countries to grow smaller rather than larger, by fracturing along national and ethnic lines. Drucker (1986) refers to this phenomenon as the intriguing coincidence of an integrating global economy and a splintering global polity. Thus the number of sovereign states in the world has increased almost fourfold (from 52 to 195) since 1945; while sub-national regions demand, and often obtain, increasing jurisdictional autonomy. Amongst these, islands stand out in particular for being geographically disposed towards being discrete administrative units, and for having successfully carved out a stable political status, which assures autonomy without sovereignty. There are 32 sovereign island and archipelagic states today; and over 100 sub-national, autonomous, island jurisdictions.

McElroy and Mahoney (1999) explain how being small, autonomous yet non-sovereign grants substantial economic advantages to island units. These benefits include: free trade with, and export preference from, the parent country; social welfare assistance; ready access to external capital through special tax concessions; availability of external labour markets through migration; aid-financed infrastructure and communications; higher quality health and educational systems; natural disaster relief; provision of costly external defence. Autonomy without sovereignty also does not hinder the development of flourishing tourism economies or offshore finance regimes, and may actually facilitate them because of easier terms of access and security. Most of these special conditions have emerged in the context of a history of a relatively benign colonial relationship - typically one that was dominated by strategic rather than economically exploitative interests.

Many small islands, because they are islands, enjoy some degree of administrative autonomy; a condition that facilitates an eventual move to sovereign statehood. Furthermore, because they are also small and somewhat isolated, and irrespective of independence, such island jurisdictions usually manage to extract some special advantages from the respective metropole. Since they have refrained from sovereignty, then they would typically therefore, jurisdictionally or 
constitutionally, enjoy more discretionary powers than any similarly sized or even larger chunks of the "mainland" (Poirine, 1998). Royle (1989) identifies 41 populated territories who have overseas territory, associated status, compact of free association or some other special, separate arrangement with a larger state; four of these are fully-fledged departments of France. Fagerlund (1997) describes the four autonomous European island regions-Faroes, Åland, Isle of Man and Channel Islands - which enjoy a special relationship, this time with that supra-national state of sorts, the European Union. Thus, the independence candle for islands has been snuffed, at least for the moment: the current status is seen as the best of both worlds - providing many of the benefits associated with political sovereignty while delegating responsibilities to, enjoying the security and reaping the material benefits of remaining in association with a larger, and typically richer, patron.

Meanwhile, national identity remains one of the most powerful forces in modern history, and at the root of much civil strife and violence. Nevertheless, sovereignty and self-determination do not appear to be-at least, for now - the obvious trajectory of peoples who see themselves as dispossessed political entities or at the losing end of federalist developments (Trompf, 1993, p. xxv). The articulation of nationalism has becomes jurisdictional but not sovereigntist.

These observations suggest that the small, insular peripheries of the world today have developed a particular set of strategies in order to maximise their options in an increasingly globalised, knowledge-driven and (by implication) metropolitan world. Some have obtained, by default or design, full political independence; but the desire for sovereignty has been tempered by more pragmatic considerations in recent times. Only one new small sovereign state-East Timor-has emerged on the world stage in the last 12 years, and this in very particular circumstances. Meanwhile, enhanced jurisdictional clout is more often pursued and secured within the context of a larger polity.

Colonialism has been the main explanatory variable behind both small island autonomy and small state sovereignty. As colonisation retreated post-1945, it left in its wake small puddles of jurisdiction, with the largest territories generally obtaining sovereignty first (starting with the largest of all, India, in 1947) and the smallest territories obtaining sovereignty last - but with the really very smallest stubbornly refusing to budge (Baldacchino, 2004, p. 79). Insularity, isolation and small size provide the geographical (if not also the administrative, logistic, cultural and historical) properties to render the existence of such jurisdictional pockets, whether sovereign or merely autonomous, much more likely.

Conversely expressed, unless a territory has enjoyed separate status within a colonial relationship, such a territory appears most unlikely to have the basic political raw material which could (eventually) be nurtured into a sovereign state, or even a quasi-sovereign one. This situation would have resulted because the administrative boundaries legitimating a distinct political identity were developed both out of sheer convenience as well as within the comfort of an internationally and domestically recognised framework of colonial rule.

Native peoples have also been quite successful in securing decision-making powers from the metropole in recent years; all the more so when they are islanders. This goes for the Aleutian Islanders (Alaska, USA); the Baffin/ Ellesmere Islanders (Canada) and the Torres Strait Islanders (Australia). Small size of population base is also likely to facilitate the granting of "autonomy".

In the case of continental states which have island provinces or regions without a history of a given, separate colonial boundary, the metropole is usually careful not to create the circumstances for any eventual devolution, ${ }^{1}$ unless exceptionally obliged to do so under force majeure: witness recent overtures to Corsica by the centralised French state, in the wake of violence and strong moves for separatism. Such a strategy could be undertaken, for example, by deliberately avoiding the creation of exclusively island-based administrative or political units, ensuring that geographic "island regions" are incorporated within larger subnational regions ${ }^{2}$; or else are themselves broken down into smaller, sub-national units: as happens in large archipelagic states like the Philippines and Indonesia. Opportunism may create historical conjunctures that facilitate such a withdrawal of autonomy; and the availability of priced resources may provide the material pretext to do so. ${ }^{3}$ 


\section{The distinctive politics of the small}

Meanwhile, failing the colonial card, island regions must rely on alternative strategies to circumvent and extract discretionary powers from the local/central state.

One way of so doing is to use and exploit the existence of a supra-national institution. This could be seen to be an outcome of the islands' lobby within the European Union, which has now identified no less than 286 island regions as the targets of "specific measures" since the adoption of the Treaty of Amsterdam (Planistat Europe, 2003). The sheer act of being defined and recognized as an "island region" could, in itself, be seen to represent an, albeit tokenistic, political victory of sorts. Of course, one could argue that such initiatives actually conspire to consolidate - rather then erode - the dependency of such island regions; and that a high political price could eventually be paid in exchange for any transfer of funds from Brussels resulting from such recognition.

However, it is becoming increasingly clear that the leap-frogging of national governments by subnational units does not necessarily depend on the existence of supra-national institutions. While the European Union serves that purpose on the small and fractious European continent, it is other states (U.S.A., Japan, eventually China and India?) as well as other cities (Boston, New York, London, Tokyo, eventually Beijing and New Delhi?) which are recognised as the choice nodes with which to develop profitable economic integration networks. The existing (residual and neo-colonial) links that many small islands have had with such nodes have become transformed into priceless, fortuitous gates, guaranteeing privileged access to key knowledge, fiscal and product markets (Royle, 1989). In these instances, the knowledge/information revolution is riding on extant political conditions and cementing their persistence.

A second device deployed by small islands as a bargaining chip is to use the management of specific local resources desired by the central state-oil, gas, mineral deposits, fishing zones, strategic bases, tourism potential, or sheer political loyalty - as leverage by a sub-national unit for extracting some degree of policy autonomy. ${ }^{4}$

Yet, even here, natural resource endowment is not as crucial a factor as is often assumed. The development and/or attraction of suitable human capital is the policy priority for many small island territories today, and especially so in the majority of cases where there is no natural resource base available to contemplate an economic alternative. Indeed, in line with the "dutch disease" hypothesis (Benjamin et al., 1989), it is not surprising to find that natural resource endowment acts as a "curse", preventing a jurisdiction from embracing the knowledge economy route (Sachs and Warner, 1995). With many small islands being naturally resource-poor, they have, simply-and luckily? - had no choice but to adopt emigration as an economic strategy and see themselves transformed into MIRAB - migration, remittances, aid and bureaucracy - economies (Bertram and Watters, 1985; King and Connell, 1999). Here, the characteristic emphasis on a brain or skill drain (e.g., McKee and Tisdell, 1990, pp. 78-89) is giving way to a rotational and cyclical human capital model (e.g. Henry, 1990; The Economist, 2003b), which encourages indigenous high-flyers to study or work abroad-preferably in the human capital metropole - and then lures them back home in suitable positions which allow them to act as nodes in their own right, exploiting and managing their overseas networks and contacts, and with suitable opportunities to act comfortably as "glocal" citizens (after Robertson, 1994). In many small island jurisdictions, the absence of local higher education institutions served to attract scholarships to and from overseas universities for the locally gifted. ${ }^{5}$ The metropolitan intellectual heartland, even though remote, can still be tapped and exploited for local ends.

A third, more radical, way is to embark unilaterally on a style of "rogue politics" which may set an island region on a confrontational path with a central government but where critical local public opinion may be swayed (also with the strategic involvement and considerable swaying influence of the mass media) in favour of the lurch and thus act to legitimate it democratically, if not legally or constitutionally. Whether such politics are indeed "maverick" is probably a matter of interpretation; however, they have been more likely to be adopted by island regions that were fully sovereign and could therefore rely on the momentum or "extantism" that sovereignty provides, in their confrontation with other, larger 
powers (Bartmann, 2002). Examples that come to mind include Iceland and the "cod wars" with Britain in the mid-20th century; Malta's negotiations with the U.K. over the military facilities on the island in the 1970s; and Vanuatu and Solomon Islands' drives for a nuclear-free Pacific in the 1980s (The Economist, 1971; Wriggins, 1976; Trompf, 1993, pp. xv-xvi, respectively). Nonsovereign regions may not enjoy the status which sovereignty provides; but they certainly can and have threatened full sovereignty if their demands for an increased localisation of economic power are not met. ${ }^{6}$

Note again that, in all the three routes identified above, smallness of population and/or land area, isolation and islandness can be deployed by the political leadership to act in concert, fuelling a distinctive territorial politics and seeking to safeguard and differentiate it from external "intervention". These departures are not exceptional: it would be wiser to see them as examples of the carving out of political niches where geography facilitates, while at the same time circumscribes, the territorial scope of any achieved/granted powers and privileges. More than that, these are also examples of alterations in geo-economic space: as economic power is transferred "upward, downward and outward from nation states" (Courchene, 1995, p. 3), jurisdiction is increasingly recognised as a very useful driver and primer for such purposes; it becomes the "catapult" which allows the entertaining of differentiation within the local state, as well as of developing an international (or better, an ultra-national) presence on the global or regional stage (e.g., McKercher, 2000).

The benefits resulting from the extraction and deployment of jurisdictional power cannot be over-estimated (Baldacchino and Milne, 2000). They usually translate in a larger localisation of control over economic and political decisions. Of course, the apex of jurisdictional powers-powers far greater in relation to the small size of a land mass or resident population - has been achieved and assiduously cultivated especially by sovereign small island states. Fisheries policy by Iceland; banking policy by Luxembourg and Liechtenstein; sustainable tourism policy by the Maldives and the Seychelles; a globally competitive textile and garments industry in Mauritius. But the political economy of success is even clearer amongst non-sovereign island territories. Discretion over taxation and offshore finance has been behind the success of such territories as Madeira, Bermuda, British Virgin Islands, Turks and Caicos, the Isle of Man and the Channel Islands; discretion over language policy, shipping registration and property ownership lie at the heart of the Aland Islands autonomy from Finland; some jurisdictional autonomy of varying degrees is enjoyed by island provinces of larger states, in spite of usually small relative size of land and population (Barbuda, Gozo, Hong Kong, Nevis, Zanzibar, the status apparte of Aruba, the départements d'outre mer of France, French Polynesia, New Caledonia, Svalbard, Hainan, Galapagos, Rapa Nui, Tasmania, the Balearics, the Canaries, the Azores...). What we have here is a combination of free-riding by the smaller, island party in the context of (deliberate?) oversight by the larger, metropolitan party, crafting in the outcome some kind of regulatory legitimacy; while the island party never foregoing the potential resort to the metropole, if and when dire straits so determine or suggest (such as budgetary shortfalls; environmental disasters; over-population; labour surplus or shortages). ${ }^{7}$ In this way, they avoid that chronic vulnerability which is supposed to plague small, island territories most of all (Briguglio, 1995). A critical question to ask is whether such departures from the norm are actually indicators of autonomy, or merely manipulations driven and controlled by the central state to its own net advantage, often without any consultation or power-sharing arrangements with the island locals? ${ }^{8}$

The premise is clear: in the hey-day of frenzied decolonisation, freedom (read sovereignty) was to be preferred, even if (as it may have turned out to be since) it become the road to perdition (read poverty and marginalisation). However, many small island territories have not taken this path. They may have been interpreted, at face value, to prefer comfortable servility to the perils of independence in a world of uncertainty (Baldacchino, 1998). But this impression must be corrected: nonsovereignty is not neo-colonial servility. Rather, following critical observation, it often is a shrewd manner of hedging one's risks, deploying a flexible and creative diplomacy, adopting free riding (in such matters as international relations, defence and security as well as currency issues), slipping 
free or through the nets of regulation and/or cultivating ultra-national economic linkages. All these measures constitute a skills repertoire that the small and powerless deploy and, being small, often get away with. They may also be providing useful regulatory escape routes for their metropolitan patrons. Furthermore, the deployment of such skills tends to command media attention and attracts sympathy. Such is the character of the dynamics of unequal dyads. Such is "the tyranny of the weak." 9

What, therefore, may be in store over the next decades is not so much a flurry of independentist movements, but attempts by sub-national jurisdictions to carve out policy discretion on a specific number of areas, and economic relationships with a specific clutch of attractive metropoles, in their favour. As the nation-state, already in itself a mythical construction of modernity, finds itself too big as well as too small to address key political problems (Bell, 1987), the pressures for internal devolution and internal federalism in the contemporary "fragmegrative" space (Rosenau, 2003) will increase, just as the incentive for supra and ultra-national agreements with other neighbouring states or components thereof will also. It is likely that, as in the case of Malta and Mauritius 40 years ago, political sovereignty as a fully fledged state will only be seriously entertained, or threatened with some degree of bluff, if what is considered a better deal by the smaller player is absolutely unacceptable to the larger. ${ }^{10}$ The same political contest is bound to occur at a supranational and regional level, as nations jockey to maintain policy autonomy while recognising that "pooled sovereignty" is the only way forward to render such bodies as the European Union even more effective. That the European Union and the euro exist at all is the outcome of such a sober assessment. "Government" (meaning decision-making by elected representatives) thus gives way irrevocably to "governance" (meaning decision-making by a plurality of networked partnerships)-(Rosenau, 2003).

One should therefore not be surprised to find that metropolitan centres are themselves seeking to develop jurisdictional clout, especially in federal political systems grounded in multi-level governance principles. Although they come very late to the politics of federalism, cities are fast realising that their ability to act politically is significantly restrained by their "constitutionlessness", as in the case of Canada (see Courchene, 2003, p. 4). Small and peripheral, particularly island, territories thus have this slight edge on the metropole, allowing the small and peripheral units to exert legitimate pressure on the central but federal state in favour of redistributive politics. In marked contrast, in circumstances (such as the U.S.A.) where cities have developed a constitutional personality and/or are in a position to lobby directly with central governments, they would be keen to thwart, or even reverse, the flow of any state "stabilisation" programmes.

A second observation concerns the financial dimensions of development. Conventional economic statistics rank countries according to gross national/domestic product or purchasing power parity standards. Small, often island, territories are doing exceptionally well on these counts. In their powerful critique of the alleged structural vulnerability of many small (often island) territories, Armstrong and Read (2002) conclude that smaller jurisdictions actually perform economically better than larger states. The citizens of Aruba, Iceland, Bermuda and French Polynesia are counted amongst the world's top ten richest people (The Economist, 2003a). That three of the above four territories are non-sovereign states is also insightful. Indeed, comparative research has shown that, on average, non-sovereign island territories tend to be richer per capita than sovereign ones (Bertram, 2004). Stopping short of full independence, while negotiating access to spoils within a larger jurisdictional framework, appears to pay off... literally. But, then: is jurisdictional clout only there for the purpose of extracting more largesse from the core?

\section{Creative political economy}

McElroy and Mahoney (1999, p. 35) conclude that small dependent (read sub-national) island territories "...remain unwilling to trade the visible security, affluence and standard of living of affiliation for the less tangible but more costly rewards of autonomy".

Similarly, Bertram (2004, p. 360) writes:

In the new century, the attributes of sovereignty, such as votes at the United Nations and possession of 
internet domains, may turn out to confer greater bargaining power than hitherto; but there is no clear incentive for presently-dependent island territories to seek independence, and good grounds for them to hold to the status quo.

While these observations highlight the pragmatic, often financial, basis for such a political stance, it underestimates the economic leverage that autonomy could grant, apart from other non-monetary, "status goods" like identity, pride, international clout and self-respect. However, autonomy is not to be necessarily translated as sovereignty.

Human nature being messy and complex, it is also possible to come across a scenario with opposite "cause-effect" dynamics: meaning that an enhanced economic prowess and business success in/by a peripheral island can nurture such sociocultural conditions which eventually lead to demands for greater autonomy. ${ }^{11}$

Armstrong and Read (1998, p. 13) have argued that many very small states, most of which are island or archipelagic territories, have managed to compensate effectively for their small size by a high quality of "endogenous policy formulation and implementation". They also contend that "further investigation of the policy stance of successful micro-states, particularly in the sphere of international political economy, is likely to be fruitful" (ibid.; my emphasis). Earlier, Katzenstein (1985) had made similar remarks in relation to small European states. This paper invites an extension of these observations to sub-national considerations. International political economy becomes domestic politics in the case of sub-national units, and falls within federalist studies where sub-national jurisdictions exist constitutionally or legally.

Sub-national considerations also connect readily with regional studies. Economic regions (e.g., Friedmann and Alonso, 1995); industrial districts (e.g., Piore and Sabel, 1984) or economic clusters (e.g., Krugman, 1991; Porter, 1998) now figure regularly in debates on economic strategy. Small nation (mainly island) states share many similarities with sub-national regions in terms of implementing strategies for economic development (e.g., Armstrong and Read, 2003); but sub-national, island jurisdictions have an even greater affinity with regions, being often seen as regions themselves. Here, islands have been leading the way as frontline zones and pioneers in a number of policy fields. These include the devolution or extraction of specific policy autonomy from "core" powers, often in the context of deals which are mutually advantageous; development of cross-border governance models by means of ultra-national links with "adjacent regions" (e.g., Armstrong and Read, 2000); and managing these often, but not necessarily, within unequal federalist arrangements ${ }^{12}$. The desirable option today appears to be that of achieving some jurisdictional autonomy for territories which lack it; but not to proceed to full sovereignty as if that were some kind of natural course of things.

The nurturing and flexing of jurisdictional muscle, de jure or defacto, is bound to be a basic feature of an increasingly integrated world. Central governments find themselves incapable of stopping this concentration of economic and technological power, and must brace themselves for the claims for corresponding political discretion, and matching claims for the devolution of governance, that are bound to follow.

It may appear contradictory, even paradoxical, that such machinations will be entertained and deployed in the face of rampant globalisation and the ever increasing interconnectedness of people and places. This observation, however, should not come as a surprise to anyone except those who consider globalisation as a deterministic, unidimensional feature. Almost a century ago, Weber (1914) had already advised that economy and society need not follow the same laws of motion: opportunities for maximising growth and development may be struck via convergent liberalisation on the economic front, where free trade is deemed beneficial; but then political deals are struck where free trade is not perceived as one's best option. Polanyi (1944) had similarly criticised economic neo-liberalism, arguing that this does not just "happen" but follows from deliberate public policy. Small island jurisdictions demonstrate how creative politics can compensate for demographic, economic and more recently, 'knowledge poverty'. Cities are waking up to this strategy.

\section{Insights for/from the knowledge-based economy}

Sovereignty gives way to autonomy; government gives way to governance; big gives way to small... 
interesting dynamics in the context of globalisation which, at face value, suggests the exact opposite.

The increasing and unstoppable interconnectedness of the world facilitates the understanding of (themselves globalizing) markets; in so doing it incentivizes the resort to techniques which may distort the market to one's advantage. Politics is the instrument to exploit economics. Federalisation is proposed in this paper as one such powerful political response to economic opportunities. Information and communication technologies, in the manner in which they connect nodes to nodes in stubborn defiance of national borders, invite a decoupling away from the conventional view of the world in terms of, literally, inter-national trade, and towards the internationalisation of subnational units.

Cities and/or regions are the often-cited examples; but small islands are prototype peripheral regions which can be singled out as the sites of "innovative treatment" within the new political economy of development. Historically, they were already seen as suitable locations for such pioneering initiatives as fortress or plantation economics (e.g., Landes, 1999). Today, they are often looked upon as relics of the past, since it is no longer an option - either for places or for firms - to survive as isolates. But the islands of the real world are anything but self-sufficient. They are by definition open economies and their survival strategies are intimately connected with the ability to source and obtain income, transfers and "rents" (Connell, 1998; Kakazu, 1994) from beyond their shores. Small islands may be looked upon as political innovators of the information age, testing out the limits of possibility which insularity, small size, location, and a measure of administrative autonomy may offer... though not without the threat that big cities may cheat them of their prized political capacities.

\section{Acknowledgments}

The support of the Social Sciences and Humanities Research Council fo Canada (SSHRC) in allocating a Standard Research Grant to the proposal "Patterns of Sub-National Autonomy amongst the Worlds's Islands" (SRG Application No. 410-2004-0397) is grately acknowledged. I am grateful to colleagues who have helped in structuring this paper's themes and contents. These include Barry Bartmann, Geoffrey Bertram, Richard Cullen, Rob Greenwood, Hideki Hasegawa, Jerome L. McElroy, Dan McMeekin, David Milne, Arni Olafsson, Iain Orr, Bruce Potter, Graeme Robertson, Stephen A. Royle, Mark Shrimpton and Henry F. Srebrnik. I also acknowledge the constructive comments of academic colleagues at the Conference on the Knowledge-Based Economy and Economic Development, held in St John's, Newfoundland, Canada, October 2003. I am obliged to Phil Cooke and Loet Leydesdorff for encouraging me to prepare this paper for eventual publication. Responsibility for all shortcomings remains my own.

\section{Notes}

1. As in the reaction by Copenhagen to Bornholm's desire for more autonomy.

2. Such as the Western Islands of Scotland which form administrative units with parts of the mainland (Skye and Lochalsh; Argyll and Bute); or the Dutch, Danish, Finnish, German, Irish and Swedish Islands. Is Newfoundland and Labrador a similar configuration?

3. As happened in the case of Cape Breton Island (now part of the Province of Nova Scotia, in Canada). Another example is that of the proposed granting of independence to St KittsNevis-Anguilla in the late 1960s. This was used by Bradshaw, then Premier of St Kitts, to tighten central control by St Kitts over the archipelago- - leading to the secession of Anguilla and its persisting status as a separate British colony.

4. Such cases include: the issue of oil and gas reserves in the discussions over the potential secession of the Faroe Islands from the Danish realm, as well as on the status of the Falkland Islands (because of oil); the granting by Westminster of special tax-raising powers related to North Sea oil/gas to the Shetland Islands; the British Virgin Islands and Bermuda (because of offshore banking) under the British Crown; India's relationship with the Andaman and Nicobar Islands - seen as having strong tourism potential; and the use of Kwalajein Atoll by the U.S. Military within the agreement of a Compact of Free Association between the Marshall Islands and the U.S.A. The cultivation of political loyalty explains most of Gozo's administrative autonomy within the Maltese state. Cullen (1990) also explores the different ways in which Australia and Canada handled the management of natural resources within their subnational jurisdictions.

5. As was the case, for example, in Cyprus before Hellenic nationalism got the better of public policy.

6. Non-island examples of this in recent years have been Québec in Canada as well as Catalonia and Euskadi/Basque 
Region (using sharply contrasting methods) in Spain. Meanwhile, Åland, Bermuda and the Isle of Man have all spawned independist movements in recent years when specific economic privileges have appeared to be under threat.

7. My thanks to Jerome L. McElroy for developing this argument.

8. Thus Royle (1997) describes the development of Batam Island as an exclusive economic zone within Indonesia, in order to exploit its proximity to Singapore. But this move was done uniltareally by Jakarta and may have intensified the powerlessness of the Batanese.

9. An expression coined by former President of Iceland, Olafur Ragnar Grimsson.

10. In their run-up to eventual independence, both Malta and Mauritius opted first to seek integration within the British state. 11. A current condition of Newfoundlanders, especially those engaged in the extraction (oil/gas) industries? (I am grateful to Mark Shrimpton for this observation).

12. For a comparative assessment of contemporary federalist arrangements affecting islands, see Watts (2000).

\section{References}

Amin, A. and N. Thrift (eds.), 1994, Globalization, Institutions and Regional Development in Europe, Oxford: Oxford University Press.

Armstrong, H.W. and R. Read, 1998. 'The International Political Economy of Micro-States: An Overview,' paper presented at Islands V Conference, University of Mauritius, Mauritius, July.

Armstrong, H.W. and R. Read, 2000, 'Comparing the Economic Performance of Dependent Territories and Sovereign Microstates,' Economic Development and Cultural Change $\mathbf{4 8}$ (2), 285-306

Armstrong, H.W. and R. Read, 2002, 'The Phantom of Liberty? Economic Growth and the Vulnerability of Small States,' Journal of International Development 14 (3), 435-458.

Armstrong, H.W. and R. Read, 2003, 'Microstates and Subnational Regions: Mutual Insustrial Policy Lessons,' International Regional Science Review 26 (1), 117-141.

Baldacchino, G., 1998, Far Better to Serve in Heaven than to Reign in Hell: Malta's Logic of Relating to the European Union in Baldacchino. Godfrey and Greenwood. Robert (ed.), Competing Strategies of Socio-Economic Development for Small Islands, Charlottetown, Canada: Institute of Island Studies, University of Prince Edward Island, pp. 213-237.

Baldacchino, G., 2004, 'Autonomous but not Sovereign? A Review of Island Sub-Nationalism,' Canadian Review of Studies in Nationalism, 31 (1-2), 77-89.

Baldacchino, G. and D. Milne (eds.), 2000, Lessons from the Political Economy of Small Islands: The Resourcefulness of Jurisdiction, Basingstoke: Macmillan.

Bartmann, B., 2002, 'Meeting the Needs of Microstate Security,' The Round Table 365, 361-374.

Bell, D., 1987, 'The World and the United States in 2013,' Daedalus 116 (1), 1-31.

Bertram, I.G., 2004, 'On the Convergence of Small Island Economies with their Metropolitan Patrons,' World Development 32 (2), 343-364.
Benjamin, N.C., S. Devarajan and R.J. Weiner, 1989, 'The Dutch Disease in a Developing Country: oil reserves in Cameroon,' Journal of Development Economics 30 (1), 71-92.

Bertram, I.G. and R.F. Watters, 1985, 'The MIRAB Economy in South Pacific Microstates,' Pacific Viewpoint 6 (4), 497-519.

Briguglio, L., 1995, 'Small Island Developing States and their Vulnerabilities,' World Development 23 (9), 1615-1632.

Connell, J., 1988. 'Sovereignty and Survival: Island Microstates in the Third World,' Research Monograph No. 3, Sydney: University of Sydney, Department of Geography.

Courchene, T.J., 1995, 'Glocalisation: The Regional/International Interface,' Canadian Journal of Regional Science $\mathbf{1 8}$ (1), 1-20.

Courchene T.J. 2003. 'Knowledge And Human Capital: The Winning ca.combo For The Information Era,' paper prepared for the TD Forum on Canada's Standard of Living, available at: http://www.td.com/economics/standard/full/ Courchene.pdf (Accessed 09 Feb 2004).

Cullen, R., 1990, Federalism in Action, NSW, Australia: Federalist Press.

Drucker P., 1986. 'The Changed World Economy,' Foreign Affairs, Spring, 3-17.

Fagerlund, N., 1997, Autonomous European Island Regions enjoying a special relationship with the European Union in Lyck Lyse (ed.), Constitutional and Economic Space of the Small Nordic Jurisdictions, Copenhagen: NordRefo, pp. 90-121.

Friedmann, J. and W. Alonso (eds.), 1995, Regional Policy: Readings in Theory and Applications, Cambridge, MA: MIT Press.

Henry, R.M., 1990, 'Cooperation in Human Resource Utilisation in the Commonwealth Caribbean,' Bulletin of Eastern Caribbean Affairs 16 (1), 25-28.

Kakazu, H., 1994, Sustainable Development of Small Island Economies, Boulder, CO: Westview Press.

Katzenstein, P.J., 1985, Small States in World Markets, Cornell, NY: Cornel University Press.

King, R. and J. Connell (eds.), 1999, Small Worlds, Global Lives: Islands and Migration, London: Pinter.

Krugman, P., 1991, Geography and Trade, Cambridge, MA: MIT Press.

Landes, D.S., 1999, The Wealth and Poverty of Nations: Why Some are so Rich and Some so Poor, New York: W.W. Norton.

McElroy, J.L. and M. Mahoney, 1999, 'The Propensity for Political Dependence in Island Microstates,' INSULA: International Journal of Island Affairs 9 (1), 32-35.

McKee, D.L. and C.A. Tisdell, 1990, Development Issues in Small Island Economies, New York: Praeger.

McKercher, W.R., 2000. 'The Isle of Man: Jurisdictional Catapult to Development,' in G. Baldacchino and D. Milne (eds.), Lessons from the Political Economy of Small Islands: The Resourcefulness of Jurisdiction, Basingstoke: Macmillan, pp. 91-106.

Ohmae, K., 2001, The Invisible Continent: Four Strategic Imperatives of the New Economy, New York: HarperBusiness.

Planistat Europe, 2003. 'Analysis of the Island Regions and Outermost Regions of the European Union-Part 1: The Island Regions and Territories, March,' available at: http:// 
europa.eu.int/comm/regional_policy/sources/docgener/studi es/pdf/ilesrup/islands_part1_summary en.pdf (Accessed 09 Feb 2004).

Piore, M. and C. Sabel, 1984, The Second Industrial Divide: Possibilities for Prosperity, New York: Basic Books.

Poirine, B., 1998, 'Should We Hate or Love MIRAB?' The Contemporary Pacific 10 (1), 65-107.

Polanyi, K. 1944. The Great Transformation, Boston MA Beacon Hill

Porter, M.E., 1998. 'Clusters and the New Economics of Competition,' Harvard Business Review, December, 77-90.

Robertson, R., 1994, 'Globalisation or Glocalisation?', Journal of International Communication, 1(1), 33-52.

Rosenau, J.N., 2003, Distant Proximities: Dynamics Beyond Globalisation, Princeton, NJ: Princeton University Press.

Royle, S.A., 1989, 'A Human Geography of Islands,' Geography 74 (1), 106-116.

Royle, S.A., 1997. 'The benefits of insularity on development: the case of Batan Island, Indonesia,' paper presented to Development Studies Association Conference, Norwich, University of East Anglia, September.

Sachs, J.D. and Warner, A.M. 1995. 'Natural Resource Abundance and Economic Growth,' NBER Working
Papers 5398, Cambridge, MA: National Bureau of Economic Research

The Economist, 1971. 'Damned Dots,' London: The Economist Magazine, July 31st, p. 16.

The Economist, 2003a. 'On the World's Rich List,' London: The Economist Magazine, May 17th, p. 33.

The Economist, 2003b. 'Brain Gain,' London: The Economist Magazine, October 11th, pp. 38, 42.

G. Trompf (ed.), 1993, Islands and Enclaves: Nationalisms and Separatist Pressures in Island and Littoral Contexts, New Delhi: Sterling Publishers.

Watts, R.L., 2000. 'Islands in Comparative Constitutional Perspective,' in G. Baldacchino and D. Milne (eds.), Lessons from the Political Economy of Small Islands: The Resourcefulness of Jurisdiction, Basingstoke: Macmillan, pp. 17-37.

Weber, M., 1914/1978, Economy and Society: An Outline of Interpretative Sociology, 2 vols, Berkeley, CA: University of California Press.

Wriggins, H.W., 1976, Up for Auction: Malta Bargains with Great Britain in Zartman Walter (ed.), The Fifty Per Cent Solution, New York: Doubleday, pp. 208-234.

Wright Mills, C., 1959, The Sociological Imagination, New York: Oxford University Press. 